\title{
Characterization of Recumbent, Ambulatory, and Postexercise Proteinuria in the Adolescent
}

\author{
MARK T. HOUSER \\ University of Nebraska Medical Center, Omaha, Nebraska 68105
}

\begin{abstract}
To better characterize the effects of body position and exercise on urinary protein excretion, carefully defined random urine samples were obtained during recumbency and following both ambulation and exercise in healthy adolescent student athletes. Albumin, lysozyme, and $\mathrm{N}$-acetyl-B-D-glucosaminidase were measured in all samples. Glomerular permeability and tubular function were assessed using the urinary albumin creatinine ratio $\left(U_{A l b} / U_{C r}\right)$, the urinary lysozyme creatinine ratio $\left(U_{L y} / U_{C r}\right)$, the urinary $\mathrm{N}$-acetyl-B-D-glucosaminidase creatinine ratio $\left(U_{\mathrm{Nag}} / \mathbf{U}_{\mathrm{Cr}}\right)$, and the urinary lysozyme albumin ratio $\left(\mathbf{U}_{\mathrm{ky}} /\right.$ $\left.U_{A l b}\right) . U_{A l b} / U_{C r}$ was significantly $(p<0.001)$ lower in recumbent urine samples than in either ambulatory or postexercise samples, although no difference was seen between the latter two groups. Furthermore, recumbent $\mathrm{U}_{\mathrm{Alb}} / \mathrm{U}_{\mathrm{Cr}}$ was higher in females $(\boldsymbol{p}<0.01)$ and postexercise $\mathrm{U}_{\mathrm{Alb}} / \mathrm{U}_{\mathrm{Cr}}$ varied significantly $(p<0.001)$, depending on the type of physical activity. $U_{\mathrm{Ly}} / \mathrm{U}_{\mathrm{Cr}}, \mathrm{U}_{\mathrm{Nag}} / \mathrm{U}_{\mathrm{Cr}}$, and $\mathrm{U}_{\mathrm{Ly}} / \mathrm{U}_{\mathrm{Alb}}$ were unaffected by either posture or physical activity. A significant correlation was found between $U_{A l b} / U_{C r}$ and $\mathrm{U}_{\mathrm{Nag}} / \mathrm{U}_{\mathrm{Cr}}(r=0.60, p=0.0001)$ and also between $U_{\mathrm{Ly}} / \mathbf{U}_{\mathrm{Cr}}$ and $U_{\mathrm{Ly}} / U_{\mathrm{Alb}}(r=0.84, p=0.001)$. In addition, urinespecific gravity was found to have a significant negative correlation with $U_{A l b} / U_{C r}(r=-0.33, p=0.001)$. The results of this study suggest that in the adolescent, recumbent albumin excretion is higher in females and that ambulation increases glomerular permeability. Exercise does not appear to induce any additional alteration in glomerular permeability, although the effects of exercise are likelyrelated to the type and severity of physical activity. Renal tubular function is unaltered by either ambulation or exercise. Furthermore, urinary albumin excretion may be increased in the face of diuresis and urinary $\mathrm{N}$-acetyl-B-Dglucosaminidase excretion may be stimulated by the effects of increasing albumin excretion. (Pediatr Res 21: 442-446, 1987)
\end{abstract}

\section{Abbreviations}

$\mathbf{U}_{\mathrm{Ly}} / \mathbf{U}_{\mathrm{Cr}}$, urinary lysozyme creatinine ratio

$\mathrm{U}_{\mathrm{Alb}} / \mathrm{U}_{\mathrm{Cr}}$, urinary albumin creatinine ratio

$\mathbf{U}_{\mathrm{Nag}} / \mathbf{U}_{\mathrm{Cr}}$, urinary $\mathbf{N}$-acetyl-B-D-glucosaminidase creatinine ratio

$\mathrm{U}_{\mathrm{Ly}} / \mathrm{U}_{\mathrm{Alb}}$, urinary lysozyme albumin ratio

ANOVA, analysis of variance

NAG, $\mathbf{N}$-acetyl-B-D-glucosaminidase

4-MU, 4-methylumbelliferone

SAS, statistical analysis system

Received August 6, 1986; accepted December 4, 1986.

Send correspondence to Mark T. Houser, M.D., University of Nebraska Medical Center, 42nd and Dewey Avenue, Omaha, NB 68105.
The normal glomerulus carefully regulates the transmural movement of plasma proteins, such that large molecules (i.e. albumin' are largely excluded from the urinary space while small proteins are freely filtered (1). Numerous studies have characterized the importance of molecular size, charge, and configuration, as well as certain biochemical and physiologic properties of the glomerular capillary that effect macromolecular transport $(1,2)$. Disorders associated with glomerular injury or dysfunction are characterized by an increase in the urinary excretion of large molecular weight proteins, while processes associated with tubular injury or dysfunction are found to have an increase in the urinary excretion of low molecular weight proteins, such as lysozyme or $B_{2}$-microglobulin (3-6). In particular, the urinary ratio of lysozyme or $B_{2}$-microglobulin to albumin is an extremely sensitive way to characterize glomerular or tubular proteinuria $(3,4)$. Furthermore, the urinary excretion of enzymes derived from renal tissue (i.e. NAG) is also a sensitive indicator of subtle renal injury and is abnormal in many glomerular or tubulointerstitial diseases (5-8).

The effects of body position and exercise on urinary protein excretion remains unsettled, especially in children. In young adults, exercise appears to induce an abnormality in glomerular permeability, although short-term exhaustive work seems to increase low molecular weight protein excretion as well (9-11). In children, urinary albumin excretion is not uniformly increased following strenuous exercise (12-15) and only limited data are available concerning the excretion of low molecular weight proteins or renal enzymes following exercise $(12,14)$. Furthermore, the effects of posture on urinary protein excretion are somewhat contradictory. Total urinary protein excretion in the upright position has been noted to be unchanged (16) or even lower than recumbent protein excretion (17) while albumin excretion is usually $(18,19)$ but not always (17) increased in the upright position. To date, no study has characterized the effects of posture and exercise in the same group of subjects using sensitive measurements of both glomerular and tubular function. We report the results of such a study in healthy adolescent student athletes.

\section{MATERIALS AND METHODS}

Subjects. One hundred-sixteen adolescents (73 females, 43 male) were recruited from high school students participating in organized interscholastic athletics in the Omaha metropolitan area. The mean age of the subjects was $15.8 \mathrm{yr}$ (females, 15.5; males, 16.2) with a range of 14-18 yr. All subjects were healthy, were not receiving medications, and had no prior history of renal or systemic disease. Furthermore, none of the subjects had an acute intercurrent illness, fever, or menstruation during the study. The females participated in volleyball $(n=22)$, basketball $(n=43)$, or soccer $(n=8)$; the males in soccer $(n=14)$ or basketball $(n=29)$. There were no significant $(p>0.2)$ age differences between any of the groups of athletes. Informed 
written consent was obtained from a parent or guardian and the subjects also gave written assent to participate in the study.

Study protocol. Random urine samples were collected under defined conditions of body position or exercise during the course of a single day. Random urine samples were utilized for this study as we $(20,21)$ and other $(14,18,22,23)$ have previously verified the accuracy of this approach to quantitate the urinary excretion of either proteins or enzymes by factoring the concentration per $\mathrm{mg}$ of urinary creatinine. Furthermore, the use of random urine samples obviates any concern about the adequacy of timed urine collections. The day prior to the study, students were supplied with a kit containing written instructions and materials for collecting the urine samples. The night prior to the study, the subjects were asked to void before retiring. The first urine sample was collected in the morning immediately after assumption of the upright position. The second sample was collected around noon of the same day, after at least $4 \mathrm{~h}$ of quiet ambulation without strenuous activity and the last was collected within 30 min after completion of athletic practice. Urine samples were refrigerated during the day and were subsequently frozen at $-20^{\circ} \mathrm{C}$ until analyzed.

Analytical procedures. Albumin was measured using a fluorescent immunoassay method as reported by Chavers et al. (24). The sensitivity of this method is $0.5 \mu \mathrm{g} / \mathrm{ml}$ and the between-run and within-run coefficients of variation using normal samples in our lab were $6.6 \%$ and $2.8 \%$, respectively. Lysozyme measurements were performed using an improved turbidimetric method as previously reported (25). This assay is linear over a concentration range of $0.01-1.0 \mu \mathrm{g} / \mathrm{ml}$ and the between-run and withinrun coefficients of variation were 9.3 and $4.8 \%$, respectively. NAG was assayed using a slight modification of the manual fluorometric method reported by Tucker et al. (26) in which the substrate concentration is increased to $0.8 \mathrm{mmol} / \mathrm{liter}$, a value closer to the $K_{m}(27)$. As urine contains inhibitors and activators of NAG activity, individual recovery techniques were utilized (27) and concentrations are reported as nmol 4-MU released per 30 -min incubation at $37^{\circ} \mathrm{C}$. The between-run and within-run coefficients of variation for this assay in our lab were 5 and $4.3 \%$, respectively. Creatinine was determined using a "true" creatinine method (28). Values obtained with this method correlate extremely well with those obtained using a standard AutoAnalyzer technique (29), in urine samples ranging in concentration from $15.8-237 \mathrm{mg} / \mathrm{dl}(r=0.98, \mathrm{y}=1.06 \times .7, n=20)$. Urine concentration was estimated by measuring specific gravity with a refractometer.

Statistical analysis. Data storage and statistical analysis were done by computer utilizing the SAS as previously reported (21, $30,31)$. As we have demonstrated that urinary protein and enzyme excretion is not normally distributed in ambulatory subjects $(20,21)$, careful assessment of the normality of distribution and homogeneity of variances was made. All variables except $U_{L y} / U_{C r}$ were normally distributed with $\log$ transformation and comparisons were done using either the one-way ANOVA and Duncan's multiple comparison procedure or a Student's $t$ test on $\log$ transformed numbers. $\mathrm{U}_{\mathrm{Ly}} / \mathrm{U}_{\mathrm{Cr}}$ comparisons were done using a nonparametric ANOVA and multiple comparison procedure or a Student's $t$ test applied to ranked data. Correlation coefficients were calculated using Pearson's product moment statistic and linear regressions using the least squares technique. Differences were considered significant if $p<0.05$ and all data are presented as the mean \pm SEM, calculated using $\log$ transformed numbers. Because of the need to use rank order analysis or log transformation, the range is presented as the 5 th to 95 th percentile. Standard procedures were used for all statistical testing (30-32).

\section{RESULTS}

The effects of body position and exercise on $\mathrm{U}_{\mathrm{Alb}} / \mathrm{U}_{\mathrm{Cr}}, \mathrm{U}_{\mathrm{Ly}} /$ $\mathrm{U}_{\mathrm{Cr}}, \mathrm{U}_{\mathrm{Nag}} / \mathrm{U}_{\mathrm{Cr}}$, and $\mathrm{U}_{\mathrm{Ly}} / \mathrm{U}_{\mathrm{Alb}}$ are given in Table $1 . \mathrm{U}_{\mathrm{Alb}} / \mathrm{U}_{\mathrm{Cr}}$ was significantly $(p<0.01)$ lower in males during recumbency, although no sex-related differences were seen during ambulation or following exercise. Albumin excretion was significantly $(p<$ 0.001 ) altered by activity and increased in the upright and postexercise samples, although $\mathrm{U}_{\mathrm{Alb}} / \mathrm{U}_{\mathrm{Cr}}$ was not significantly different between the latter two groups in either males or females. Lysozyme and NAG excretion were unaffected by either posture or physical activity. However, $\mathrm{U}_{\mathrm{Ly}} / \mathrm{U}_{\mathrm{Cr}}$ was significantly $(p<$ 0.01 ) lower in males during ambulation and following exercise.

Table 2. Postexercise albumin creatinine ratios in male and female athletes*

\begin{tabular}{llccc}
\hline & & & \multicolumn{2}{c}{$\begin{array}{c}\text { Albumin/creatinine } \\
\left(\mathrm{U}_{\mathrm{Alb}} / \mathrm{U}_{\mathrm{Cr}}, \mu \mathrm{g} / \mathrm{mg}\right)\end{array}$} \\
\cline { 3 - 5 } \cline { 4 - 5 } Sport & Sex & Subjects $(n)$ & Mean $\dagger$ & Range \\
\hline Volleyball & $\mathrm{F}$ & 22 & $8.0 \pm 1.1^{1}$ & $3.5-15.7$ \\
Soccer & $\mathrm{M}$ & 13 & $10.7 \pm 1.1^{1}$ & $6.3-19.6$ \\
Basketball & $\mathrm{M}$ & 27 & $10.8 \pm 1.1^{1}$ & $3.0-43.0$ \\
Soccer & $\mathrm{F}$ & 8 & $15.2 \pm 1.3^{2}$ & $2.9-37.6$ \\
Basketball & $\mathrm{F}$ & 39 & $17.4 \pm 1.1^{2}$ & $7.0-87.2$ \\
\hline
\end{tabular}

* Data calculated using log transformed numbers. Values expressed as the mean \pm SEM and range is presented as the 5th to 95 th percentile.

$\dagger$ Groups with different numbers were significantly $(p<0.001)$ different.

Table 1. Urinary albumin, lysozyme, and NAG excretion, and urinary lysozyme albumin ratio during recumbency and following ambulation and exercise*

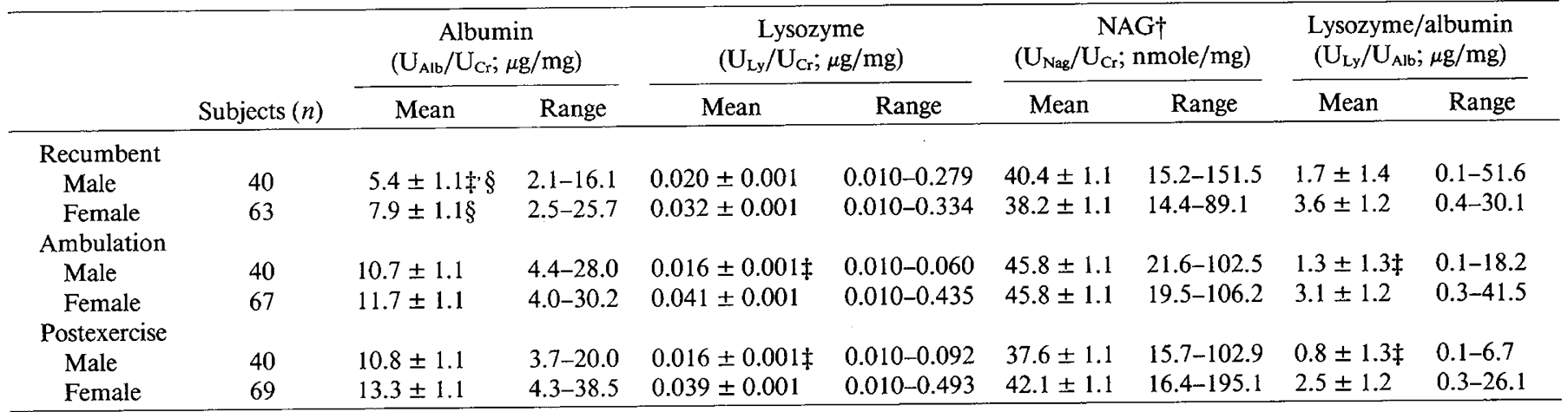

* Data calculated using log transformed numbers. Values expressed as the mean \pm SEM and range is presented as the 5 th to 95 th percentile.

$\dagger \mathrm{NAG}$ units are nmol 4-MU released per 30 -min incubation at $37^{\circ} \mathrm{C}$.

$\ddagger p<0.01$ compared to female.

$\S p<0.001$ compared to ambulation or postexercise. 
$\mathrm{U}_{\mathrm{Ly}} / \mathrm{U}_{\text {Alb }}$ was noted to decrease progressively in the upright and postexercise samples in both males and females. Although these values for $U_{\mathfrak{L y}} / U_{\text {Alb }}$ were not statistically different, a borderline significant $p$ value was observed in the male subjects $(p=0.06)$. As with $\mathrm{U}_{\mathrm{Ly}} / \mathrm{U}_{\mathrm{Cr}}, \mathrm{U}_{\mathrm{Ly}} / \mathrm{U}_{\mathrm{Alb}}$ was significantly $(p<0.01)$ lower in males during ambulation and following exercise.

The effects of differing types of physical activity on urinary albumin excretion are given in Table 2. Postexercise albumin excretion varied from $8.0 \mu \mathrm{g} / \mathrm{mg}$ creatinine in the volleyball players to $17.4 \mu \mathrm{g} / \mathrm{mg}$ creatinine in the female basketball players. The volleyball players and males participating in soccer and basketball had postexercise $\mathrm{U}_{\mathrm{Alb}} / \mathrm{U}_{\mathrm{Cr}}$ values that were significantly $(p<0.001)$ lower than the female soccer and basketball players.

To determine if protein or enzyme excretion correlated with body position or activity in our study, comparisons were made between each variable in the recumbent and upright, recumbent and postexercise, and the upright and postexercise periods. Indeed, a significant correlation was found between upright and postexercise $\mathrm{U}_{\mathrm{Alb}} / \mathrm{U}_{\mathrm{Cr}}(r=0.32, p=0.008)$ although no correlation was found between recumbent and upright $\mathrm{U}_{\mathrm{Alb}} / \mathrm{U}_{\mathrm{Cr}}(r=$ $0.12, p=0.24)$ or between recumbent and postexercise $\mathrm{U}_{\mathrm{Alb}} / \mathrm{U}_{\mathrm{Cr}}$ $(r=-0.03, p=0.79)$. None of the other variables was found to have a significant $(p>0.20)$ correlation between any of the study periods.

In an attempt to evaluate the effects of urine concentration on albumin or enzyme excretion, or possible relationships between the various parameters of glomerular permeability and tubular function, a correlation matrix was generated. These data are presented in Table 3. As can be seen, urine specific gravity was noted to demonstrate a very significant negative correlation with $\mathrm{U}_{\mathrm{Nag}} / \mathrm{U}_{\mathrm{Cr}}(r=-0.43)$ and $\mathrm{U}_{\mathrm{Alb}} / \mathrm{U}_{\mathrm{Cr}}(r=-0.33)$ and a significant but weak negative correlation with $\mathrm{U}_{\mathrm{Ly}} / \mathrm{U}_{\mathrm{Cr}}(r=-0.18)$. In addition, strong correlations were found between $\mathrm{U}_{\mathrm{Alb}} / \mathrm{U}_{\mathrm{Cr}}$ and $\mathrm{U}_{\mathrm{Nag}} / \mathrm{U}_{\mathrm{Cr}}(r=0.60)$ and between $\mathrm{U}_{\mathrm{Ly}} / \mathrm{U}_{\mathrm{Cr}}$ and $\mathrm{U}_{\mathrm{Ly}} / \mathrm{U}_{\mathrm{Alb}}(r=$ $0.84)$.

\section{DISCUSSION}

Urinary albumin excretion, as assessed by $\mathrm{U}_{\mathrm{Alb}} / \mathrm{U}_{\mathrm{Cr}}$, was found to be lower in the recumbent position in healthy adolescent athletes in our study (Table 1). This observation largely confirms the recent report of Davies et al. (18), in which nighttime values for $\mathrm{U}_{\mathrm{Alb}} / \mathrm{U}_{\mathrm{Cr}}$ were lower in both males and females. However, in this latter study $\mathrm{U}_{\mathrm{Alb}} / \mathrm{U}_{\mathrm{Cr}}$ was higher in females during both recumbency and during the day while actual albumin excretion was increased only in the daytime samples. This might suggest that recumbent $\mathrm{U}_{\mathrm{Alb}} / \mathrm{U}_{\mathrm{Cr}}$ was higher in females as a reflection of

Table 3. Correlation coefficients noted when comparisons were made between various markers of glomerular permeability, tubular function, and urine concentration*

\begin{tabular}{cccll}
\hline & $\begin{array}{c}\text { Urine } \\
\text { specific gravity }\end{array}$ & $\mathrm{U}_{\mathrm{Alb}} / \mathrm{U}_{\mathrm{Cr}}$ & $\mathrm{U}_{\mathrm{Ly}} / \mathrm{U}_{\mathrm{Cr}}$ & $\mathrm{U}_{\mathrm{Nag}} / \mathrm{U}_{\mathrm{Cr}}$ \\
\hline $\mathrm{U}_{\mathrm{Alb}} / \mathrm{U}_{\mathrm{Cr}}$ & $-0.329 \dagger$ & & 0.174 & 0.603 \\
& 0.0001 & & 0.002 & 0.0001 \\
& & & & \\
$\mathrm{U}_{\mathrm{Ly}} / \mathrm{U}_{\mathrm{Cr}}$ & 0.183 & 0.174 & & 0.273 \\
& 0.001 & 0.002 & & 0.0001 \\
$\mathrm{U}_{\mathrm{Nag}} / \mathrm{U}_{\mathrm{Cr}}$ & -0.428 & 0.603 & 0.273 & \\
& 0.0001 & 0.0001 & 0.0001 & \\
$\mathrm{U}_{\mathrm{Ly}} / \mathrm{U}_{\mathrm{Alb}}$ & 0.089 & -0.045 & 0.837 & 0.078 \\
& 0.11 & 0.43 & 0.0001 & 0.17 \\
\hline
\end{tabular}
319).

$\dagger$ The first number in each pair is the correlation coefficient $(r)$ and the second is the $p$ value noted for the correlation. lower urinary creatinine excretion (34). The absence of a gender difference in upright or postexercise $\mathrm{U}_{\mathrm{Alb}} / \mathrm{U}_{\mathrm{Cr}}$ in our study and the observations of Rowe et al. (35), in which quantitative recumbent albumin excretion was higher in females, suggests that recumbent albumin excretion might also be greater in the female. These contradictory sex-related differences in quantitative recumbent albumin excretion in the studies of Davies et al. (18) and Rowe et al. (35) are somewhat difficult to reconcile. Both studies included both children and adolescents, although Davies et al. (18) utilized a much larger cohort of subjects and albumin excretion was corrected for differences in body surface area. This latter point is crucial as it might have induced a bias in the data reported by Rowe et al. (35). For the present, the issue of sex-related differences in recumbent quantitative albumin excretion remains unsettled although clearly recumbent $\mathrm{U}_{\mathrm{Alb}} / \mathrm{U}_{\mathrm{Cr}}$ is higher in the female. Recumbent and upright values for $\mathrm{U}_{\mathrm{Alb}} / \mathrm{U}_{\mathrm{Cr}}$ is our study were comparable to those reported by Davies et al. (18), even though the latter study included a cohort of younger children.

We are unaware of previous data carefully evaluating the effect of ambulation on lysozyme or NAG excretion, or the urinary ratio of low and high molecular weight proteins. However, Suzuki et al. (36) characterized urinary protein excretion during recumbency and following lordosis in a small group of normal subjects and children with postural proteinuria; lordosis did not alter lower molecular weight protein excretion in either group. In our study, recumbent and upright values for $\mathrm{U}_{\mathrm{Ly}} / \mathrm{U}_{\mathrm{Cr}}, \mathrm{U}_{\mathrm{Nag}} / \mathrm{U}_{\mathrm{Cr}}$, and $\mathrm{U}_{\mathrm{ky}} / \mathrm{U}_{\mathrm{Alb}}$ were all similar and not statistically different (Table 1). We can offer no reasonable explanation for the significant difference between male and females for upright $\mathrm{U}_{\mathrm{Ly}} / \mathrm{U}_{\mathrm{Cr}}$ or $\mathrm{U}_{\mathrm{Ly}} / \mathrm{U}_{\mathrm{Alb}}$, as we have not found sex-related differences for these variables in upright uncontrolled urine samples (33) (Houser MT, unpublished observations). Previously, we have noted a significant ( $p$ $<0.01$ ) increase in $\mathrm{U}_{\mathrm{Ly}} / \mathrm{U}_{\mathrm{Cr}}$ in urine samples having a lower specific gravity (33). However, in our current study, no significant differences in urine specific gravity were found between either periods $(p>0.1)$ or sexes $(p>0.2)$, and thus do not explain these differences in $\mathrm{U}_{\mathrm{Ly}} / \mathrm{U}_{\mathrm{Cr}}$ or $\mathrm{U}_{\mathrm{Ly}} / \mathrm{U}_{\mathrm{Alb}}$. The student athletes reported herein do not appear to have any evidence of renal tubular dysfunction, as $\mathrm{U}_{\mathrm{Ly}} / \mathrm{U}_{\mathrm{Cr}}$ was actually somewhat lower than previously reported, especially in males (33). As lysozyme is handled by an extremely effective renal transport process that demonstrates constant fractional reabsorption over a widely variable filtered load, it seems unlikely that minor differences in either plasma lysozyme concentration or glomerular filtration rate would cause these differences (37). However, as filtered lysozyme is greater than $99.8 \%$ reabsorbed in normal subjects, it is apparent that very minimal differences in the tubular handling of lysozyme could cause a significant change in its urinary excretion (38). Further studies will be needed to fully evaluate the issue of sex-related differences in renal tubular lysozyme transport.

Exercise has long been recognized to alter urinary protein excretion, and its effects have been well characterized in the adult $(9-11,39,40)$. These studies have demonstrated that moderate physical activity induces an apparent abnormality in glomerular permeability, manifest as an increase in the urinary excretion of albumin and other high molecular weight proteins $(9,39)$. On the other hand, strenuous, exhaustive exercise appears to increase the urinary excretion of both albumin and lysozyme or $\mathrm{B}_{2^{-}}$ microglobulin, thus demonstrating both a "glomerular" and "tubular" pattern $(9-11,39)$. In children, the effects of exercise on urinary protein excretion have only recently been characterized and are contradictory (12-15). Huttenen et al. (12) reported the first study characterizing proteinuria induced by exhaustive exercise in children, the majority of whom were adolescents. In this study, exercise significantly increased quantitative albumin excretion and the urinary albumin $\mathrm{B}_{2}$-microglobulin ratio, although actual $B_{2}$-microglobulin excretion was not affected (12). These findings suggested a "glomerular" type proteinuria. How- 
ever, subsequent studies have not been able to confirm these findings (13-15). Resting and postexercise albumin excretion were not significantly different in normal children or adolescents in any of the latter studies, even though similar types of strenuous exercise were used. As it has been demonstrated in normal adults that albumin excretion differs depending on the work load placed on the subject (40), it is likely that the divergent observations noted in these studies (12-15), reflect differences in the severity or duration of exercise, the physical condition of the subjects (12), or even the timing of sample collection following exercise (41). The observation in our study that differing types of physical activity were associated with widely variable values for postexercise $U_{\mathrm{Alb}} / \mathrm{U}_{\mathrm{Cr}}$ (Table 2) supports this conclusion. As all of the previous studies evaluating exercise proteinuria in children or adolescents $(12-15,41)$ have been done using a standard exercise protocol on a bicycle ergometer or treadmill, the results of our study are not strictly comparable to any of these observations. However, mean values for upright and postexerise $U_{A l b} / U_{\mathrm{Cr}}$ in our study were not different and were nearly identical to those reported by Jefferson et al. (13). However, Brouhard et al. (14) reported postexercise values for $\mathrm{U}_{\mathrm{Alb}} / \mathrm{U}_{\mathrm{Cr}}$ that were somewhat higher. We did not find any change in tubular function or tubular enzyme excretion following exercise $\mathrm{U}_{\mathrm{Ly}} / \mathrm{U}_{\mathrm{Cr}}$ and $\mathrm{U}_{\mathrm{Nag}} / \mathrm{U}_{\mathrm{Cr}}$ were unaltered (Table 1). These data are compatible with previous reports by Huttenen et al. (12) and Poortmans et al. (41) for $\mathrm{B}_{2^{-}}$ microglobulin and with Brouhard et al. (14) for $U_{\mathrm{Nag}} / \mathrm{U}_{\mathrm{Cr}}$ following exercise. Thus, it would appear that in normal adolescents, exercise is not usually associated with any abnormality in either glomerular permeability or tubular function. However, the statistically significant but weak correlation noted between upright and postexercise $\mathrm{U}_{\mathrm{Alb}} / \mathrm{U}_{\mathrm{Cr}}(r=0.32, p=0.008)$ in this study, suggests that upright and postexercise albumin excretion may be regulated by similar factors in healthy subjects.

Several interesting observations were made during this study concerning interrelationships between albumin and enzyme excretion or the effects of urine concentration on these parameters. $\mathrm{U}_{\mathrm{Alb}} / \mathrm{U}_{\mathrm{Cr}}$ demonstrated a strong correlation with $\mathrm{U}_{\mathrm{Nag}} / \mathrm{U}_{\mathrm{Cr}}(r=$ $0.60, p=0.0001)$ and a significant but very weak correlation with $\mathrm{U}_{\mathrm{Ly}} / \mathrm{U}_{\mathrm{Cr}}(r=0.17, p=0.002)$. Although a strong correlation has previously been established between urinary NAG and either protein (7) or albumin (8) excretion in subjects with glomerulonephritis, such a relationship has not, to our knowledge, been previously reported in normal subjects. As there was no apparent tubular dysfunction in our subjects and $U_{\mathrm{Ly}} / \mathrm{U}_{\mathrm{Alb}}$ tended to fall from recumbent to postexercise samples, the increase in $\mathrm{U}_{\mathrm{Alb}} /$ $U_{\mathrm{Cr}_{r}}$ noted in the upright and postexercise samples probably reflects an alteration in glomerular permeability and hence, an increase in the filtered load of albumin. Renal tubular albumin absorption should increase in this circumstance and seems to occur primarily by absorptive endocytosis (42). This transport process appears to be located primarily within the proximal convoluted tubule (43), which is also the same tubular segment that demonstrates the highest content of the lysosomal enzyme NAG (44). Following absorption by tubular epithelial cells, albumin is hydrolyzed within phagolysosomes and degradation products are released at the peritubular membrane $(42,43)$. Although only speculative, the strong correlation noted between $\mathrm{U}_{\mathrm{Alb}} / \mathrm{U}_{\mathrm{Cr}}$ and $\mathrm{U}_{\mathrm{Nag}} / \mathrm{U}_{\mathrm{Cr}}$ might suggest that the absorptive endocytosis and lysosomal degradation of albumin is associated with the urinary loss of the lysosomal enzyme NAG. On the other hand, the weak correlation between $\mathrm{U}_{\mathrm{Alb}} / \mathrm{U}_{\mathrm{Cr}}$ and $\mathrm{U}_{\mathrm{Ly}} / \mathrm{U}_{\mathrm{Cr}}(r=$ 0.17 ) suggests that albumin absorption is a minimal factor in the regulation of low molecular weight protein transport. Further clarification concerning the effects of albumin absorption on NAG excretion or low molecular weight protein transport will obviously require in vitro study using the isolated perfused proximal tubule.

The ratio of lysozyme or $\mathrm{B}_{2}$-microglobulin to albumin has been shown to be an effective marker of glomerular or tubular injury in subjects with renal disease $(3,4)$ and has been used to study changes in glomerular and/or tubular function in response to exercise in both normal subjects and diabetics $(10,12,41)$. In our study, $\mathrm{U}_{\mathrm{Ly}} / \mathrm{U}_{\mathrm{Alb}}$ was shown to correlate highly with $\mathrm{U}_{\mathrm{Ly}} / \mathrm{U}_{\mathrm{Cr}}$ $(r=0.84, p=0.0001)$ while no correlation was found with $\mathrm{U}_{\mathrm{Alb}} /$ $\mathrm{U}_{\mathrm{Cr}}(r=-0.04, p=0.43)$. This would suggest that in normal subjects $U_{\mathrm{Ly}} / \mathrm{U}_{\mathrm{Alb}}$ is a much better marker of tubular than glomerular function.

We have previously noted a relationship between fractional urine flow rate and either lysozyme $(r=0.79)$ or NAG $(r=0.65)$ excretion in healthy subjects under the stress of hydropenia and oral water loading (21). Furthermore, we have shown a significant negative correlation between random $U_{\mathrm{Ly}} / \mathrm{U}_{\mathrm{Cr}}$ and urine specific gravity $(r=-0.33, p=0.0001)$ although no correlation was found with $U_{\mathrm{Nag}} / \mathrm{U}_{\mathrm{Cr}}(r=0.08)$ (33). In our current study, urine specific gravity was found to correlate negatively with $\mathrm{U}_{\mathrm{Nag}} / \mathrm{U}_{\mathrm{Cr}}$ $(r=-0.43), \mathrm{U}_{\mathrm{Alb}} / \mathrm{U}_{\mathrm{Cr}}(r=-0.33)$, and $\mathrm{U}_{\mathrm{Ly}} / \mathrm{U}_{\mathrm{Cr}}(r=-0.18)$. Although all correlations were statistically significant $(p<0.001)$, the relationship between urine specific gravity and $U_{\mathrm{Ly}} / \mathrm{U}_{\mathrm{Cr}}$ was much weaker and the correlation with $U_{\mathrm{Nag}} / \mathrm{U}_{\mathrm{Cr}}$ was much stronger than noted in our previous study (33). We are somewhat uncertain as to a reasonable explanation for these differences, as the range of urine specific gravity was comparable in both studies. However, our previous report utilized a larger cohort of subjects (427) ranging in age from 3 months to $61 \mathrm{yr}$ and urine samples were collected in an uncontrolled manner during the day (33). This variation in age and manner of sample collection might explain these differences. The negative correlation between $U_{\text {Alb }} /$ $\mathrm{U}_{\mathrm{Cr}}$ and urine-specific gravity is of interest and suggests that albumin excretion may be higher in the face of diuresis. This observation is compatible with the report of Jarrett et al. (45) who noted a high correlation between urine flow rate and albumin excretion in both diabetic $(r=0.78)$ and normal subjects $(r=0.89)$. However, such a correlation was not found in the study of Huttenen et al. (12). However, this discrepancy may reflect differences in study design. In the study reported by Jarret et al. (45) recumbent samples were primarily utilized while in the study of Huttenen et al. (12) short-term resting and postexercise samples were used; urine flow rate was widely variable in both studies. These observations might suggest that urine flow rate is an important factor in urinary albumin excretion only during recumbency. However, in our study the highest correlation between urine-specific gravity and $\mathrm{U}_{\mathrm{Alb}} / \mathrm{U}_{\mathrm{Cr}}$ was seen in the postexercise samples $(r=-0.41, p=0.0001)$. Micropuncture data in isolated perfused rabbit proximal convoluted tubules indicate that under physiologic conditions, albumin absorption is proportional to fluid reabsorption (42), although these two processes can be disassociated by chloroquine, which almost completely inhibits albumin absorption without affecting fluid reabsorption (46). These observations might, in part, explain the apparent relationship between urine concentration and albumin excretion in our study. Currently, it is unclear whether any of these relationships are merely coincidence or whether they represent some real physiologic interaction. Additional studies will obviously be needed to further characterize these issues.

In summary, the observations made in this study suggest that in the adolescent, ambulation induces an increase in glomerular permeability that is unassociated with any alteration in tubular function. Furthermore, exercise does not appear to induce any additive alteration in either glomerular permeability or tubular function. However, the wide variability in postexercise $U_{\mathrm{Alb}} / \mathrm{U}_{\mathrm{Cr}}$ seen with differing types of activity suggests that glomerular permeability may be altered by certain types of exercise.

Acknowledgments. The author is indebted to Mary Frances Jahn for help in conducting this study, to Shu Wei for excellent technical assistance, and to Mary Caniglia for preparation of the manuscript.

\section{REFERENCES}

1. Kanwar YS 1984 Biology of disease: biophysiology of glomerular filtration and proteinuria. Lab Invest 51:7-21 
2. Deen WM, Bridges CR, Brenner BM 1983 Biophysical basis of glomerular permselectivity. J Membr Biol 71:1-10

3. Peterson A, Ervin E, Berggard I 1969 Differentiation of glomerular, tubular and normal proteinuria: determinations of urinary excretion of $\mathrm{B}_{2}$-microglobulin, albumin, and total protein. J Clin Invest 48:1189-1198

4. Zager RA 1980 Urinary protein markers of tubulointerstitial nephritis. Invest Urol 18:197-202

5. Vanderlinde RE 1981 Urinary enzyme measurements in the diagnosis of renal disorders. Ann Clin Lab Sci 11:189-201

6. Morgan DB 1982 Assessment of renal tubular function and damage and their clinical significance. Ann Clin Biochem 19:307-313

7. Kunin CM, Chesney RW, Craig WA, England AC, DeAngelis C 1978 Enzy muria as a marker of renal injury and disease: studies of $\mathrm{N}$-acetyl-Bglucosaminidase in the general population and in patients with renal disease. Pediatrics 62:751-760

8. Hultberg B, Ravnskov U 1981 The excretion of N-acetyl-B-glucosaminidase in glomerulonephritis. Clin Nephrol 15:33-38

9. Poortmans JR 1985 Postexercise proteinuria in humans: facts and mechanisms. JAMA 253:236-240

10. Poortmans JR, Vancalck B 1978 Renal glomerular and tubular impairment during strenuous exercise in young women. Eur J Clin Invest 8:175-178

11. Poortmans JR 1972 Effect of exercise on the renal clearance of amylase and lysozyme in humans. Clin Sci 43:115-120

12. Huttunen NP, Kaar ML, Pietilainen M, Vierikko P, Reinila M 1981 Exerciseinduced proteinuria in children and adolescents. Scand J Clin Lab Invest 41:583-587

13. Jefferson IG, Greene SA, Smith MA, Smith RF, Griffin NKG, Baum JD 1985 Urine albumin to creatinine ratio-response to exercise in diabetes. Arch Dis Child 60:305-310

14. Brouhard BH, Allen K, Sapire D, Travis LB 1985 Effect of exercise on urinary $\mathrm{N}$-acetyl-beta-D-glucosaminidase activity and albumin excretion in children with type I diabetes mellitus. Diabetes Care 8:466-472

15. Dahlquist $G$, Aperia A, Carlsson L, Linne $T$, Persson B, Thoren $C$, Wilton $\mathbf{P}$ 1983 Effect of metabolic control and duration on exercise-induced albuminuria in diabetic teen-agers. Acta Paediatr Scand 72:895-902

16. Wagner MG, Smith FG, Tinglof BO, Cornberg E 1968 Epidemiology of proteinuria. J Pediatr 73:825-832

17. Mahurkar SD, Dunea G, Pillay VKG, Levine H, Gandhi V 1975 Relationship of posture and age to urinary protein excretion. Br Med J 1:712-714

18. Davies AG, Postlethwaite RJ, Price DA, Burn JL, Houlton CA, Fielding BA 1984 Urinary albumin excretion in school children. Arch Dis Child 59:625630

19. Robinson RR, Glenn WG 1964 Fixed and reproducible orthostatic proteinuria: IV. Urinary albumin excretion by healthy human subjects in the recumbent and upright postures. J Lab Clin Med 64:717-723

20. Houser M 1984 Assessment of proteinuria using random urine samples. J Pediatr 104:845-848

21. Houser MT 1986 The effect of hydropenia and oral water loading on renal lysozyme handling and N-acetyl-B-D-glucosaminidase excretion in man. Ann Clin Biochem 23:453

22. Barratt TM, McLaine PN, Soothill JF 1970 Albumin excretion as a measure of glomerular dysfunction in children. Arch Dis Child 45:496-501

23. Ginsberg JM, Chang BS, Matarese RA, Garella S 1983 Use of single voided urine samples to estimate quantitative proteinuria. N Engl J Med 309:15431546

24. Chavers BM, Simonson J, Michael AF 1984 A solid phase fluorescent immunoassay for the measurement of human urinary albumin. Kidney Int 25:576-
578

25. Houser MT 1983 Improved turbidimetric assay for lysozyme in urine. Clin Chem 29:1488-1493

26. Tucker SM, Boyd PJR, Thompson AE, Price RG 1975 Automated assay of Nacetyl-B-glucosaminidase in normal and pathological human urine. Clin Chem Acta 62:333-339

27. Vigano A, Cavanna G, Capodaglio P, Assael BM, Salmona M 1981 Methodological and clinical aspects of urinary-N-acetyl-glucosaminidase in pediatric subjects. Biochem Med 25:26-33

28. Yatzidis H 1974 New method for direct determination of "true" creatinine. Clin Chem 20:1131-1134

29. Arant BS, Edelmann CM, Spitzer A 1972 The congruence of creatinine and inulin clearances in children: use of the technicon autoanalyzer. J Pediatr 81:559-561

30. SAS Institute Inc. 1982 SAS User's Guide: Basics. SAS Institute Inc., Cary, NC

31. SAS Institute Inc. 1982 SAS User's Guide: Statistics. SAS Institute Inc., Carey,

32. Zar J 1974 Biostatistical Analysis, Prentice Hall, Englewood Cliffs, NJ

33. Houser MT 1986 The effects of age and urine concentration on lysozyme and $\mathrm{N}$-acetyl-B-D-glucosaminidase (NAG) content in urine. Ann Clin Biochem 23:297-302

34. Schwartz GJ, Gauthier B 1985 A simple estimate of glomerular filtration rate in adolescent boys. J Pediatr 106:522-526

35. Rowe DJF, Hayward M, Bagga H, Betts F 1984 Effect of glycaemic control and duration of disease on overnight albumin excretion in diabetic children. Br Med J 289:957-959

36. Suzuki Y, Shimao S, Okada T, Ishimoto F, Akiba N 1983 Quantitative determination of urinary protein components of children with postural proteinuria. Eur J Pediatr 140:268-272

37. Maack T 1975 Renal handling of low molecular weight protein. Am J Med 58:57-64

38. Pruzanski W, Wilson DR 1977 Renal handling of endogenous lysozyme in man. J Lab Clin Med 90:61-67

39. Campanacci L, Faccini L, Englaro E, Rustia R, Guarnieri GF, Barat R, Carraro M, De Zotti R, Micheli W 1981 Exercise-induced proteinuria. Contrib Nephrol 26:31-41

40. Vittinghus E, Mogensen CE 1982 Graded exercise and protein excretion in diabetic man and the effect of insulin treatment. Kidney Int 21:725-729

41. Poortmans $J$, Dorchy $H$, Toussaint D 1982 Urinary exercise of total proteins, albumin and $\mathrm{B}_{2}$-microglobulin during rest and exercise in diabetic adolescents with and without retinopathy. Diabetes Care 5:617-623

42. Park $\mathrm{CH}$, Maack $\mathrm{T} 1984$ Albumin absorption and catabolism by isolated perfused proximal convoluted tubules of the rabbit. $\mathbf{J}$ Clin Invest 73:767777

43. Park CH, Camargo MJF, Maack T 1985 Tubular handling of proteins. Absorption of albumin by isolated perfused proximal convoluted tubules of the rabbit. In: Avram MM (ed) Proteinuria. Plenum Publishing Corporation, New York, pp 37-56

44. Bourbouze R, Baumann FC, Bonvalet JP, Farman N 1984 Distribution of Nacetyl-B-D-glucosaminidase isoenzymes along the rabbit nephron. Kidney Int 25:636-642

45. Jarrett RJ, Verma NP, Keen H 1976 Urinary albumin excretion in normal and diabetic subjects. Clin Chim Acta 71:55-59

46. Park $\mathrm{CH}$, Maack T 1983 Albumin (ALB) absorption and metabolism by proximal convoluted tubules of the rabbit: Dissociation from fluid reabsorption by chloroquine (CQ). Fed Proc 42:480 